\title{
METODE PENELITIAN SASTRA LOKAL: SEBUAH RUMUSAN AWAL
}

\author{
Awla Akbar Ilma ${ }^{1}$, Puri Bakthawar ${ }^{2}$ \\ ${ }^{12}$ Staf Pengajar di Fakultas Sastra Universitas Pamulang \\ 1 email: awlaakbar24@gmail.com \\ 2email: puribakthawar@gmail.com
}

\begin{abstract}
Abstrak
Munculnya karya sastra lokal di Indonesia akhir-akhir ini secara massif penting untuk direspon. Hal pertama yang perlu dilakukan ialah merumuskan metode penelitian yang sesuai dengan pendekatan dan permasalahan yang dominan muncul dalam karya sastra lokal. Permasalahan tersebut antara lain, narasi budaya lokal dan kearifan lokal yang ditampilkan di dalam karya sastra, serta relasi antara narasi budaya lokal dengan masyarakat, pengarang, dan pembaca. Berdasarkan permasalahan tersebut, penulis meyakini bahwa pendekatan klasik M.H Abrams, yang terdiri dari pendekatan objektif, mimetik, ekspresif, dan pragmatik relevan untuk menjawab dan menjelaskan permasalahan. Sementara metode penelitian yang digunakan ialah metode deskripsi analisis dengan langkah kerja sesuai asumsi dari masing-masing 4 pendekatan tersebut. Hal yang penting dalam penelitian sastra lokal ialah penelusuran data melalui sumber pustaka dan wawancara. Data wawancara penting untuk membangun pemahaman mengenai konteks budaya dari masyarakat yang digambarkan oleh karya. Sementara analisis yang penting dilakukan ialah mendeteksi sikap dari karya sastra dalam memandang budayanya sendiri dan budaya lain dalam interaksi budaya. Analisis ini merupakan langkah awal dalam mendeteksi munculnya sikap-sikap negatif dalam tumbuh kembangnya budaya lokal, yakni sikap konservatif dan persaingan budaya yang tidak sehat.
\end{abstract}

Kata Kunci: Sastra Lokal, Metode Penelitian, Interaksi Budaya.

\section{Pendahuluan}

Dalam konteks kesusastraan Indonesia pasca-Reformasi, marak bermunculan karya sastra yang mengeksplorasi tema-tema lokalitas. Hal itu sejalan dengan semangat reformasi. Melalui kacamata posmodernisme, dapat diketahui adanya pergeseran narasi besar bangsa Indonesia dari pusat ke pinggir. Ketika era Orde Baru keberadaan pusat wacana ditunjukkan melalui kebijakan-kebijakan yang bersifat 
Jawasentris dan bahkan Jakartasentris. Akan tetapi, pada era reformasi muncul dan berkembang narasi-narasi kecil yang ditunjukkan melalui keberadaan dan eksistensi daerah sehingga wacana dan prioritas-prioritas tidak lagi berpusat di Jawa dan Jakarta. Situasi itu menunjukkan adanya pergeseran yang membawa pada arah keterbukaan dan nilai-nilai keberagaman.

Dalam lanskap kesusastraan Indonesia, pergeseran itu nampak cukup dominan. Hal itu ditandai melalui keberadaan karya sastra pada masa Orde Baru yang terbatas berasal dan beredar di Jakarta. Baik dari sisi penerbitan, latar belakang pengarang, maupun isu-isu yang diangkat dalam karya sastra, karya-karya yang beredar tersebut nyaris bersifat Jakarta-sentris. Dapat dikatakan, narasi pembanding atas kecenderungan Jakarta-sentris tersebut relatif berasal dari karya-karya penulis Yogyakarta yang juga cukup kuat dalam aktivitas kebudayaannya. Meskipun demikian, jumlahnya tidaklah terlalu signifikan jika dibandingkan dengan narasi kesusastraan Indonesia era Orde Baru yang bersifat Jakarta-sentris.

Pasca-Reformasi, mulai muncul karya-karya sastra yang bernafaskan lokalitas. Hal itu setidaknya dapat diukur dari beberapa fenomena. Fenomena pertama, dalam kurun tahun 2000-an hingga setidaknya tahun 2017, Kompas sebagai media massa nasional memuat cerpen yang menarasikan tema lokalitas. Narasi lokalitas tersebut tersebar secara merata dari Aceh, Minang, Palembang, Jawa, Bali, Mandar, Rote, Makassar, hingga Papua. Di antara karya tersebut bahkan terpilih sebagai cerpen pilihan Kompas yang diterbitkan dalam bentuk buku setiap tahunnya. Hal ini menggambarkan betapa perkembangan kesusastraan nasional memberi ruang bagi tumbuh dan berkembangnya karya sastra dengan tema lokalitas.

Fenomena kedua ialah munculnya karya-karya sastra bernuansa lokalitas, utamanya novel, yang kemudian mampu memenangkan berbagai sayembara sastra yang juga cukup terlegitimasi di Indonesia, misalnya Sayembara Novel Dewan Kesenian Jakarta (DKJ) atau Penghargaan Kusala Sastra Khatulistiwa. Beberapa novel tersebut di antaranya Lampuki karya Arafat Nur, Jatisaba karya Ramayda Akmal, Isinga: Roman Papua karya Dorothea Rosa Herliany, atau Orang-orang 
Oetimu karya Felix K. Nesi. Keempat novel tersebut, secara berturut-turut, merepresentasikan narasi lokalitas berbagai daerah di Indonesia, antara lain: Aceh, Jawa-Banyumasan, Papua, dan Nusa Tenggara Timur.

Dengan maraknya karya sastra yang bernuansa lokalitas ini membuka potensi bagi berkembangnya kritik sastra Indonesia mutakhir. Secara spesifik, kajian akademik atas fenomena sastra lokal tersebut berpotensi untuk menggali lebih dalam kekayaan budaya Indonesia. Kajian akademik tersebut sekaligus dapat menjadi medium bagi dialogisasi antar budaya dalam rangka mengembangkan cakrawala wacana kebudayaan Indonesia secara lebih luas.

Meskipun demikian, sejauh penelusuran penulis, serangkaian metode penelitian yang dapat digunakan secara spesifik untuk meneliti sastra lokal Indonesia dirasa masih terbatas. Oleh karena itu, diperlukan adanya formulasi metode penelitian yang secara khusus diarahkan untuk mengkaji sastra bernuansa lokalitas ini. Tulisan ini berusaha membuat rumusan awal mengenai metode penelitian sastra lokal, dengan harapan mampu memberikan panduan awal untuk membedah serta mengkaji bagaimana narasi lokalitas kedaerahan yang muncul terutama dalam karya-karya sastra Indonesia.

\section{Metode Penelitian}

Tulisan ini merupakan upaya awal untuk merumuskan metode penelitian dengan objek material sastra lokal. Meskipun demikian, tulisan tetap berasumsi bahwa pendekatan terhadap karya sastra yang dipaparkan oleh M.H. Abrams, yakni pendekatan ekspresif, mimetik, objektif, dan pragmatik dapat digunakan. Hanya saja, fokus pembahasan dapat ditekankan pada permasalahan yang spesifik dengan objek kajian sastra lokal, antara lain isu lokalitas dan kearifan lokal yang diwacanakan oleh cerita serta makna dari wacana tersebut terkait sikap atas interaksi budaya yang dihadirkan. Sikap demikian dapat diwujudkan melalui tindakan menerima keberadaan budaya lain dan bahkan mempelajarinya, atau justru menolak budaya lain dan membenarkan budaya sendiri. Dalam membahas rumusan awal ini, tulisan 
menggunakan metode kritis, yakni mengajukan pertanyaan-pertanyaan yang mungkin terhadap objek kajian sastra lokal serta mengaitkan pertanyaan tersebut dengan 4 pendekatan yang dipaparkan oleh M.H. Abrams sebagai kemungkinan teori dan metodenya. Sementara dalam melaporkan hasil rumusan metode digunakan metode deskriptif, yakni memaparkan melalui uraian kelimat-kalimat dan tabel untuk memperjelasnya.

\section{Pembahasan}

Bagian ini akan memaparkan tumbuh dan berkembangnya fenomena sastra lokal dalam kesusastraan Indonesia, serta berusaha memformulasi pertanyaanpertanyaan penelitian hingga metode penelitian sastra lokal. Pemaparan akan dilakukan secara sistematis, mulai dari kondisi keberadaan karya sastra lokal, pendekatan dalam penelitian sastra lokal, metode penelitian sastra lokal, contoh identifikasi lokalitas cerita melalui pendekatan objektif dan gambaran analisis secara mimetik. Penjelasaan diakhiri dengan analisis preventif terhadap perkembangan sastra lisan melalui analisis tingkat konsertatif dan toleransi cerita dalam memandang budayanya dalam pertemuannya dengan budaya lain.

\section{Kondisi Keberadaan Karya Sastra Lokal di Indonesia}

Sebagaimana dijelaskan pada latar belakang, pasca reformasi membuka bagi munculnya karya sastra dengan tema yang beragam salah satu yang cukup dominan ialah karya sastra dengan tema lokalitas. Kondisi ini merupakan satu memontum penting sebab membuka peluang bagi tumbuh dan berkembangnya karya yang menggambarkan ekspresi, gagasan, dan persoalan lokal, yang pada era Orde Baru cenderung tidak diperhatikan bahkan ditabukan melalui idiom SARA. Melalui karya sastra lokal ini akan diketahui pula kearifan lokalitas dari suatu daerah tertentu sebab menurut Ahimsa-Putra (2009: 39-40) kearifan merupakan kekayaan budaya yang tersimpan dalam bahasa dan sastra suatu masyarakat. Dengan menganalisisnya akan terungkap berbagai kearifan lokal suatu masyarakat, yang kemudian akan dapat direvitalisasi untuk kepentingan masyarakat itu sendiri (Ahimsa-Putra, 2009: 32). 
Meskipun demikian, situasi ini tetap perlu dijaga dengan baik. Meskipun merupakan momentum positif, situasi ini bisa berbalik menjadi ancaman, misalnya menguatknya sikap konservatif sehingga rentan konflik identitas, atau munculnya persaingan antarbudaya yang berimbas pada perpecahan. Upaya pencegahan perlu dilakukan agar situasi yang harmonis tetap terjaga di tengah tumbuh dan berkembangnya kesadaran-kesadaran lokal itu. Oleh karena itu, kajian terhadap sastra lokal dapat dimulai dari, pertama identifikasi terhadap narasi budaya yang dimunculkan oleh karya sastra lokal. Kedua memahami relasi antara narasi tersebut dengan konteks sosial masyarakat, pengarang, dan pembaca. Ketiga, menganalisis nilai-nilai kearifan lokal yang terkandung di dalam karya sastra dan keempat menyusun rekomendasi tentang cara mengembangkan budaya dan kearifan lokal serta menyusun strategi pengelolaan atas keberagaman budaya yang dihadirkan oleh karya sastra lokal tersebut.

Secara konkret, seorang peneliti dapat merumuskan sejumlah pertanyaan penelitian antara lain: a). "Mengapa karya sastra Indonesia yang muncul akhir-akhir ini bertemakan lokalitas?", b). "Bagaimana tema lokalitas yang digambarkan dalam karya sastra Indonesia?”, c). "Seperti apa lokalitas yang digambarkan dalam karya sastra Indonesia?”, d). "Siapa saja pengarang karya sastra lokal Indonesia?, e). "Bagaimana latar belakang para pengarang yang mengangkat tema lokalitas tersebut", f). "Mengapa para pengarang tersebut menulis karya sastra dengan tema lokalitas?", g). "Bagaimana hubungan antara tema lokalitas dengan kondisi sosial masyarakatnya?", h). Apa saja nilai-nilai kearifan lokal yang disampaikan oleh karya sastra lokal tersebut? i). "Siapa pembaca karya sastra yang mengangkat tema lokalitas tersebut”?, j). “Apa fungsi dari karya sastra dengan tema lokalitas demikian?” dan k). “bagaimana dampak dari munculnya tema lokalitas dalam karya sastra Indonesia?". Untuk menjawab pertanyaan-pertanyaan tersebut dibutuhkan pendekatan-pendekatan yang tepat sesuai dengan pertanyaan yang diajukan. Pertanyaan a, g, dan k dapat menggunakan pendekatan mimetik, pertanyaan $\mathrm{b}, \mathrm{c}, \mathrm{h}$ dapat menggunakan 
pendekatan objektif, pertanyaan d, e, dan f dapat menggunakan pendekatan ekspresif, pertanyaan i dan $\mathrm{j}$ dapat menggunakan pendekatan pragmatik.

\section{Alternatif Pendekatan Dalam Penelitian Karya Sastra Lokal}

Berdasarkan pertanyaan rumusan masalah di atas, penulis berasumsi bahwa pendekatan karya sastra yang dirumuskan oleh Abrams dapat digunakan untuk membantu menjelaskannya. Abrams dalam buku The Mirror and The Lamp: Romantic Theory and the Critical Tradition. (1976) membagi pendekatan terhadap teks sastra menjadi 4, yakni pendekatan mimetik, ekspresif, objektif, dan pragmatik. Pendekatan mimetik berupaya menjelaskan hubungan antara karya sastra dengan kenyataan. Pendekatan ekspresif berupaya menjelaskan hubungan antara karya sastra dengan pengarang. Pendekatan objektif berupaya menjelaskan hubungan antara karya sastra dengan unsur-unsur pembangunnya, dan pendekatan pragmatik menjelaskan hubungan antara karya sastra dengan pembacanya. Keempat pendekatan ini memiliki asumsi masing-masing yang berbeda dan saling melengkapi satu sama lain. Bagi pendekatan mimetik, karya sastra ialah tidak bisa dilepaskan dengan kenyataan. Ia adalah cerminan dari kenyataan.

Sementara bagi pendekatan ekspresif karya sastra merupakan karya kreatif dari seorang pengarang. Dengan demikian, pengaranglah yang menjadi sasaran penelitian. Kemudian pendekatan objektif berasumsi bahwa karya sastra merupakan karya otonom yang tersistem. Dengan demikian, pemaknaan dan segala hal mengenai karya sastra dapat diketahui dengan cara menjelaskan unsur-unsur pembangunnya dan hubungan antar unsur tersebut. Terakhir, pendekatan pragmatik berasumsi bahwa pembacalah yang paling penting sebab ia merupakan pihak yang memaknai dan mengkonkretkan makna. Tanpa pembaca karya sastra hanyalah artefak yang tak berarti. Dengan demikian, seorang peneliti dapat memilih salah satu objek baik karya sastra lisan maupun karya sastra tulis dan salah satu memilih dari empat pendekatan. 


\section{Metode Penelitian Sastra Lokal Indonesia}

Metode penelitian mengemukakan secara teknis strategi yang digunakan dalam penelitian. Pemahaman atas metodologi akan memberikan kejelasan apa dan bagaimana metode penelitian budaya harus dioperasikan (Endraswara, 2006: 5). Oleh karena itu, metode penelitian lebih banyak berbicara mengenai langkah-langkah penelitian secara operasional. Biasanya, metode penelitian langsung menukik pada masalah penentuan judul, perumusan masalaah, pemilihan informan, penetuan setting, teknis analisis, dan pengambilan data (Endraswara, 2006: 6).

Menurut Endraswara (2006: 85), bidang budaya cenderung menggunakan perspektif kualitatif untuk mengungkap fenomena humaniora yang kompleks. Pengukuran tidak penting dalam penelitian budaya karena tidak akan menemukan generalisasi. Perspektif kualitatif budaya justru mengedepankan pengamatan yang berkualitas. Tegasnya, kajian budaya lebih menekankan aspek "kualitas" fenomena, bukan pada aspek "kuantum" jumlah tertentu. Oleh karena itu, deskripsi menjadi kata kunci yang perlu dipegang teguh oleh para peneliti budaya dari perspektif kualitatif. Hal itu ditegaskan oleh pernyataan Bogdan dan Taylor (1975: 5) bahwa kajian kualitatif adalah prosedur penelitian yang menghasilkan data deskriptif berupa katakata tertulis atau lisan dari orang-orang dan perilaku.

Dengan demikian, dalam menerapkan pendekatan mimetik digunakan data-data deskriptif, yakni data-data kemasyarakatan di dalam teks sastra dan data-data yang kemasyarakatan secara nyata. Analisis ditujukan untuk mengidentifikasi dan menjelaskan relasi kedua kategori data tersebut. Sementara dalam pendekatan ekspresif digunakan data-data deskripsif, yakni data-data seperti pemikiran, kepribadian, dan pandangan dunia dalam teks dan data-data berupa biografi dan pemikiran pengarang. Analisis ditujukan untuk mengidentifikasi dan menjelaskan relasi kedua kategori data tersebut.

Kemudian pendekatan objektif menggunakan data-data berupa unsur-unsur pembangun karya sastra tersebut dan relasi antar unsurnya. Analisis ditujukan untuk mengetahui unsur-unsur pembangun karya, makna karya, dan narasi budaya yang 
dihadirkan oleh karya. Narasi budaya tersebut dapat berupa kearifan-kearifan dari suatu masyarakat daerah tertentu. Terakhir pendekatan pragmatik menggunakan data berupa data tekstual mengenai seluk beluk pembaca dan relasinya dengan data tekstual karya sastra. Analisis ditujukan untuk memahami pemaknaan pembaca terhadap karya sastra.

Hal penting dengan penelitian sastra lokal ialah proses pengumpulan data. Proses ini dapat ditelusuri melalui studi pustaka dan studi lapangan. Studi pustaka ialah penelusuran melalui sumber-sumber pustaka yang memaparkan tentang budaya dan situasi dari masyarakat yang memproduksi karya sastra, riwayat hidup dan pemikiran seorang pengarang, atau karya-karya lain yang mendukung penelitian lokalitas. Bentuk sumber pustaka tersebut dapat berupa karya ilmiah maupun dalam bentuk teks fiksi. Sementara studi lapangan ialah penelusuran sumber-sumber konkret melalui teknik wawancara, kuesioner, dan diskusi kelompok (FGD). Studi lapangan ini dapat dimanfaatkan untuk melakukan pengumpulan data sekaligus untuk melakukan konfirmasi terhadap informasi tekstual yang diperoleh dari sumber pustaka.

Dalam hal ini peneliti dapat mewawancarai komunitas dan penulis sastra lokal untuk dijadikan data penelitian. Data penelitian ini kemudian dianalisis untuk mengetahui hubungan antara keberadaan karya sastra lokal dengan penulis lokal. Secara sosiologis melalui studi ini kita dapat mengetahui berapa jumlah penulis lokal yang tertarik menulis tema lokalitas? Sejauh mana para penulis tersebut memahami pengertian sastra lokal? Bagaimana cara para penulis lokal menulis cerita lokal? Apa motivasi para penulis lokal menulis tema lokal? Bagaimana para penulis mengembangkan tema lokalitas? Pertanyaan-pertanyaan itu dapat digunakan untuk mengetahui secara sosiologis situasi lapangan di daerah dan posisi para penulis lokal tersebut dalam proses kreatifnya. Melalui studi ini, peneliti dapat kemudian mengaitkannya secara sosiologis hubungan antara karya sastra lokal dengan keberadaan penulis lokal, serta permasalahan lokal. 


\section{Identifikasi Lokalitas dan Kearifan Lokal dalam Karya Sastra}

Untuk menganalisis isu lokalitas dan kandungan kearifan lokal dalam karya sastra Indonesia digunakan pendekatan objektif. Pendekatan ini menekankan pada unsur-unsur dan relasi antar unsur yang membangun karya sastra. Dalam hal ini, penelitian memanfaatkan data kualitatif berupa kata, kalimat, dan wacana yang bersifat deskriptif. Untuk mengkategorikan unsur-unsur tersebut dapat digunakan teori bantu yang sejalan dengan pendekatan ini, yakni teori strukturalisme menurut Robert Stanton. Menurut Stanton dalam buku Teori Fiksi (2007) karya sastra tersusun atas tiga unsur, yakni fakta cerita, sarana sastra, dan tema. Tema merupakan unsur pokok yang mendasari cerita. Sebagai abstraksi dari keseluruhan cerita, tema dapat diungkapkan dengan satu kata atau satu kalimat. Sementara fakta cerita, terdiri dari tiga hal yakni, karakter, latar, dan alur. Karakter merupakan watak yang melekat pada diri seorang tokoh di dalam cerita. Sementara latar merupakan tempat dan suasana yang mendasari suatu konflik cerita. Dan alur merupakan rangkaian peristiwa yang memiliki hubungan sebab akibat. Ketiga unsur ini dapat menjadi kriteria dominan dalam mendeteksi nilai dan kadar lokalitas di dalam karya sastra.

Analisis tokoh lokalitas dapat dimulai melalui identifikasi nama diri dan karakter yang melekat pada tokoh tersebut. Kedua hal ini dapat digunakan untuk mendeteksi keberadaan tema lokalitas di dalam cerita. Hal ini karena penamaan nama diri cenderung terikat oleh budaya dan nilai-nilai ideal dari suatu masyarakat tertentu sehingga nama diri secara langsung dapat menggambarkan budaya asal dari seorang tokoh. Sementara latar juga sangat penting diperhatikan sebab latar merupakan tempat dan suasana yang mendasari cerita. Jika latar tempatnya mengacu kepada nama-nama daerah tertentu maka kecenderungan untuk mengungkapkan tema dan nilai lokalitas dominan. Alur merupakan unsur pokok. Melalui alur permasalahan dan konflik cerita terbangun. Oleh karena itu, analisis terhadap alur cerita dapat mengungkapkan hal-hal seperti keberhasilan menguatkan budaya lokal, permasalahan interaksi dan benturan antarbudaya, dan menyampaikan kearifan-kearifan lokal dari masyarakat tertentu. 
Sarana sastra merupakan unsur pendukung yang digunakan oleh penulis untuk mengemas fakta cerita menjadi estetik sehingga dapat diterima dengan baik dan menghibur pembaca. Sarana sastra antara lain terdiri dari gaya bahasa, judul, simbol, dan sudut pandang. Gaya bahasa merupakan unsur yang dapat digunakan untuk mengidentifikasi tingkat lokalitas di dalam karya sastra. Jika karya sastra menggunakan gaya bahasa dan kalimat-kalimat bahasa daerah maka berkecenderungan mengangkat lokalitas cukup dominan. Selain itu, judul juga berpengaruh. Judul biasanya menggambarkan inti cerita. Oleh karena itu, analisis terhadap judul dapat mendeteksi apakah karya tersebut mengangkat tema lokalitas atau tidak serta seperti apa inti cerita lokalitas tersebut. Hal yang tak penting ialah simbol. Budaya daerah kaya akan simbol-simbol. Oleh karena itu, keberadaan simbol budaya dapat dianalisis untuk melihat eksistensi budaya daerah, sikap dan rasa percaya diri masyarakatnya, serta kemungkinan cerita memaknai simbol-simbol budaya tersebut.

Tabel identifikasi lokalitas dan kearifan lokal dalam karya sastra

\begin{tabular}{|l|l|}
\hline Unsur-unsur cerita & Identifikasi Lokalitas Cerita \\
\hline Karakter & Penamaan nama diri tokoh dan karakter tokoh \\
\hline Latar & Nama daerah dan suasana daerah \\
\hline Alur & Permasalahan budaya dan penyampaian kearifan lokal \\
\hline Gaya bahasa & Menggunakan gaya bahasa dan logat daerah \\
\hline Judul & Mengangkat permasalahan lokal dan budaya \\
\hline Simbol & Mengangkat simbol-simbol budaya lokal \\
\hline
\end{tabular}

Hal yang paling penting dalam analisis strukturalisme ialah relasi antar unsur. Oleh karena itu, analisis atas bagian-bagian unsur tersebut kemudian dilanjutkan dengan analisis relasi antar unsur. Dengan analisis ini, akan diperoleh satu inti utama cerita yang disebut sebagai tema. Dalam kajian sastra lokal, analisis tema harus sampai pada pemahaman mengenai isu lokalitas yang digambarkan di dalam 
keseluruhan unsur. Isu lokalitas itu dapat berupa pernyataan seperti menguatnya budaya lokal, tantangan penguatan budaya lokal, interaksi antarbudaya, mengikisnya budaya lokal, pentingnya menjaga kearifan lokal, dan sebagainya.

\section{Memahami Sastra Lokal Melalui Pendekatan Mimetik}

Selain dapat dipandang melalui analisis strukturalisme, keberadaan karya sastra lokal dapat pula ditempatkan secara mimetic dengan mengaitkannya dengan kenyataan yang menjadi sumber inspirasinya. Sebagaimana diketahui, masing-masing daerah di Indonesia memiliki kekayaan budaya lokal. Oleh karena itu, analisis memetik merupakan analisis penting untuk melihat antara lain: sejauh mana karya sastra lokal menggambarkan kenyataan budaya daerahnya? budaya dan tradisi seperti apa yang digambarkan oleh karya sastra lokal? Sejauh mana karya sastra daerah terinspirasi oleh kekayaan daerahnya? Seperti apa tanggapan kritis karya sastra lokal terhadap budaya daerahnya? Bagaimana karya sastra menanggapi isu benturan budaya, antara budaya lokal satu dengan budaya lokal lainnya, antara budaya lokal dengan budaya modern, dan sebagainya? dan sebagainya. Dengan demikian melalui pendekatan ini akan diketahui hubungan antara karya sastra lokal dengan budaya dan tradisi yang melatarbelakanginya sekaligus juga menjawab pertanyaan tentang bagaimana eksistensi budaya lokal, dinamika kebudayaan lokal, dan permasalahanpermasalahan yang dihadapi masyarakat lokal yang diekspresikan di dalam teks sastra.

\section{Parameter Lokalitas: Sikap Konservatif dan Toleransi}

Dalam penelitian sastra lokal, selain kita dapat mengidentifikasi unsur-unsur lokalitas dalam karya sastra melalui pendekatan objektif dan mimetik, hal yang juga penting ialah memahami maksud dan pesan dari karya sastra tersebut. Terkait hal itu, analisis terhadap karya sastra lokal dapat difokuskan pada analisis isu-isu daerah yang hadirkan serta respon karya sastra tersebut terhadap perkembangan budaya lokal di daerah lain. Dengan kata lain, peneliti dapat menganalisis bagaimana sikap karya sastra dalam memandang budaya lokal daerahnya, serta bagaimana sikap karya sastra 
dalam merespon lokalitas dari daerah yang lain. Secara spesifik, sikap ini dapat dibagi dalam beberapa kriteria pertanyaan, yakni

a. Apakah karya sastra lokal bersikap membenarkan budayanya sendiri dan menolak budaya lain?

b. Apakah karya sastra lokal membenarkan budayanya sendiri namun terbuka dengan budaya lain?

c. Apakah karya sastra lokal menolak budayanya sendiri sekaligus juga menolak budaya lainnya?

d. Apakah karya sastra lokal menolak budayanya sendiri dan membenarkan budaya lainnya?

e. Apakah karya sastra lokal secara kritis menerima budayanya sekaligus menerima budaya lain dan bahkan mempelajarinya?

Pertanyaan-pertanyaan ini penting untuk dijawab untuk mengetahui sejauhmana karya sastra daerah merespon budayanya sendiri dan merespon keberadaan budaya lainnya. Jika karya sastra tersebut cenderung membenarkan budanya sendiri dan menolak budaya lain, maka ada kecenderungan untuk bersikap konservatif, namun jika karya sastra tersebut cenderung terbuka dengan budaya lain dan bahkan mempelajarinya maka karya sastra tersebut cenderung bersikap toleransi. Kadar konservatif dan toleransi demikian merupakan analisis penting untuk mengetahui bagaimana sikap pengarang dan karya sastra lokal dalam memahami konstelasinya dengan budaya-budaya lainnya.

\section{Kesimpulan}

Tulisan ini merupakan langkah awal untuk merespon perkembangan sastra lokal yang kian marak di era reformasi sampai saat ini. Keberadaan sastra lokal tersebut perlu mendapatkan perlakukan khusus dengan berfokus pada pertanyaanpertanyaan penelitian yang berupaya menggali kearifan lokal, isu lokalitas, serta relasi antara isu tersebut dengan realitas masyarakat dan pembaca. Sementara hal 
yang juga penting ialah menyusun rekomendasi pengembangan budaya lokal dan strategi mengelola keberagaman budaya. Tulisan ini memberi saran dalam menjawab pertanyaan-pertanyaan tersebut digunakan pendekatan klasik, yakni objektif, mimetik, ekspresif, dan pragmatik. Metode yang digunakan ialah metode deskripsi analisis dengan langkah kerja sesuai dengan asumsi dari masing-masing pendekatan tersebut. Idealnya sumber data dalam penelitian lokalitas ini didapat melalui penelusuran terhadap sumber pustaka dan wawancara. Data wawancara ini penting untuk memahami konteks budaya lokal yang digambarkan oleh karya sastra. Dan hal yang juga penting ialah memahami bagaimana sikap cerita dalam memandang budayanya sendiri dan budaya lain dalam interaksi antarbudaya. Analisis ini merupakan tindakan pengawasan terhadap ancaman negatif dari menguatnya budaya lokal seperti konservatifisme dan persaingan budaya.

\section{Daftar Pustaka}

Abrams, M. H. 1976. The Mirror and The Lamp: Romantic Theory and the Critical Tradition. New York: Oxford University Press.

Ahimsa-Putra, Heddy Shri. 2009. Bahasa, Sastra, Dan Kearifan Lokal Di Indonesia. Mabasan-Vol. 3 No. 1 Januari-Juni 2009: 30--57

Bogdan dan Taylor. 1975. Metodologi Penelitian Kualitatif. Bandung: Remadja.

Endraswara. 2006. Metode, Teori, Teknik, Penelitian Kebudayaan: Ideologi,. Epistemologi dan Aplikasi. Yogyakarta. Pustaka Widyatama.

Stanton, Robert. 2007. Teori Fiksi. Yogyakarta: Pustaka Pelajar. 